\title{
PENGEMBANGAN LEMBAR KERJA SISWA KELAS VII SMP BERBASIS PENDEKATAN SAINTIFIK PADA MATERI HIMPUNAN
}

\author{
Muhamad Akbar Maharati' ${ }^{1}$, Drajat Friansah ${ }^{2}$, Lucy Asri Purwasi ${ }^{3}$ \\ Program Studi Pendidikan Matematika STKIP PGRI Lubuklinggau 1,2,3 \\ muhamadakbarrr837@gmail.com ${ }^{1}$
}

\begin{abstract}
ABSTRAK
Penelitian ini bertujuan untuk mengembangkan Lembar Kerja Siswa berbasis Pendekatan Saintifik pada Materi Himpunan dan untuk mengetahui kualitas LKS dilihat dari aspek kevalidan dan kepraktisan. Penelitian ini merupakan penelitian pengembangan yang mengacu pada model pengembangan ADDIE, yaitu analisis, perancangan, pengembangan, implementasi, dan evaluasi. Tahap analisis meliputi (1) analisis kebutuhan; (2) analisis kompetensi dan instruksional. Tahap desain meliputi (1) penyusunan rancangan LKS; (2) membuat instrumen penelitian. Tahap pengembangan meliputi (1) pengembangan LKS; (2) validasi LKS; (3) revisi LKS; (4) ujicoba kelompok kecil. Tahap implementasi ujicoba kelompok besar. Tahap evaluasi meliputi penilaian kualitas LKS. Subjek dalam penelitian ini adalah siswa kelas VII SMP Xaverius Lubuklinggau. Instrumen yang digunakan untuk mengukur kualitas LKS meliputi angket ahli dan angket kepraktisan siswa. Angket ahli digunakan untuk mengukur kevalidan LKS sedangkan angket kepraktisan siswa digunakan untuk mengukur kepraktisan LKS. Produk penelitian berupa Lembar Kerja Siswa Berbasis Pendekatan Saintifik pada Materi Himpunan kelas VII SMP. Hasil penelitian menunjukkan (1) kualitas bahan ajar dilihat dari aspek kevalidan termasuk dalam kategori valid dengan skor rata-rata 3,08 berdasarkan penilaian tiga dosen ahli (ahli bahasa, materi dan media); dan (2) kualitas bahan ajar dilihat dari aspek kepraktisan dikategorikan sangat praktis dengan skor ratarata 3,43 berdasarkan hasil respon siswa terhadapLKS.
\end{abstract}

Kata kunci : LKS, saintifik, himpunan

\begin{abstract}
The purpose of this research is to create valid and practical Set Theory Student Worksheets based on the Scientific Approach. This is development research using the ADDIE development model, which stands for analysis, design, development, implementation, and evaluation. (1) needs analysis; (2) competency and instructional analysis are all part of the analysis phase. The design phase consists of (1) preparing a draft of the worksheets and (2) creating research instruments. (1) worksheet development; (2) worksheet validation; (3) worksheet revision; and (4) small group trial comprise the development phase. Phase one of the implementation process consists of a large group trial. The evaluation stage includes a review of the worksheets' quality. This study's participants were seventh-grade students at SMP Xaverius Lubuklinggau. Expert questionnaires and student practicality questionnaires were used to assess the quality of the developed worksheets. The expert questionnaire was
\end{abstract}


used to assess the worksheets' validity, while the student practicality questionnaire was used to assess their usability. The findings revealed that (1) the quality of teaching materials viewed from the perspective of validity was included in the valid category with an average score of 3.08 based on the assessment of three expert lecturers (linguists, materials, and media experts); and (2) the quality of teaching materials viewed from the perspective of practicality is categorized as very practical with an average score of 3.43.

Keywords : worksheets, scientific, set theory

\section{PENDAHULUAN}

Matematika merupakan bidang studi yang memiliki peranan penting dalam dunia pendidikan. Matematika perlu diberikan kepada siswa di semua jenjang pendidikan untuk membekali siswa dengan kemampuan berpikir kritis, logis, sistematis, analitis, dan kreatif, serta kemampuan dalam bekerja sama (Wijaya, Dewi, dan Purnamasari, 2018; Pebianto et al., 2019). Hal ini dipersiapkan untuk menghadapi perubahan-perubahan di dalam kehidupan dan dunia yang selalu mengalami perubahan dan perkembangan.

Pada pembelajaran abad ini siswa dituntut untuk terampil berkomunikasi secara aktif, kritis dan terampil memecahkan masalah. Pembelajaran adalah proses interaksi antara siswa, antara siswa dan pendidik, dan antara siswa dan sumber lainnya pada suatu lingkungan belajar yang berlangsung secara edukatif, agar siswa dapat membangun sikap, pengetahuan keterampilannya untuk mencapai tujuan yang telah ditetapkan (Sufairoh, 2016). Pada proses pembelajaran guru harus menggunakan pendekatan yang sistematik agar siswa mampu memecahkan masalah yang nanti diperlukan dalam kehidupan sehari-hari.

Menurut Anwar (2014) titik berat kurikulum 2013 bertujuan untuk mendorong siswa agar mampu lebih baik dalam melakukan observasi, bertanya dan mengkomunikasikan yang mereka peroleh atau mereka ketahui setelah menerima materi pembelajaran di sekolah. Pendekatan saintifik adalah proses pembelajaran yang dirancang sedemikian rupa agar siswa secara aktif mengkonstruksi konsep, hukum atau prinsip melalui tahapan-tahapan mengamati untuk mengidentifikasi atau menemukan masalah, merumuskan masalah, mengajukan atau merumuskan hipotesis, mengumpulkan data dengan berbagai teknik, menganalisis data, menarik kesimpulan dan mengkomunikasikan konsep, hukum atau prinsip yang ditemukan (Daryanto, 2014).

Selain itu guru perlu memilih media dan bahan ajar yang tepat dan sesuai dengan karakteristik materi dengan mempertimbangkan kebutuhan siswa demi mencapai tujuan pembelajaran. Pemilihan serta penggunaan bahan dalam proses pembelajaran guna menunjang keberhasilan suatu pembelajaran yang tepat diharapkan dapat meningkatkan efektivitas pembelajaran serta dapat meningkatkan mutu pembelajaran, yang apabila dikembangkan sesuai dengan kebutuhan guru dan siswa. Sebagaimana yang diungkapkan oleh Nasution (2016) bahwa bahan ajar sangat penting bagi guru dan siswa. Guru akan mengalami kesulitan dalam meningkatkan efektivitas pembelajaran jika tanpa disertai bahan ajar. Begitu pula bagi siswa, tanpa adanya bahan ajar siswa akan mengalami kesulitan dalam belajarnya. Salah satu jenis bahan ajar yang dapat digunakan dalam proses 
pembelajaran adalah Lembar Kerja Siswa.

Dalam LKS akan dimuatkan materi, ringkasan, tugas yang berkaitan dengan materi dan terdapat arahan untuk memahami materi yang diberikan serta terdapat tempat untuk menuliskan jawaban, hal ini akan membuat siswa belajar mandiri dan mempermudah proses pembelajaran (Jayanti dan Wiratomo, 2017). Pada bahan ajar yang ada belum secara optimal membuat siswa untuk aktif dalam mencari dan membangun konsep dari pelajarannya (Zulfah, 2017).

Berdasarkan hasil observasi dengan salah satu guru mata pelajaran matematika di SMP Xaverius Lubuklinggau diketahui bahwa guru belum mengembangkan LKS sebagai bahan mengajar. Berdasarkan analisis LKS yang telah dilakukan, salah satu LKS yang dipakai di sekolah tidak memiliki indikator pendekatan saintifik yaitu mengamati, menanya, menalar, mencoba dan mengkomunikasikan. Untuk bahan ajar yang digunakan dalam proses belajar hanya menggunakan buku paket dari Kemendikbud 2016. Buku paket yang digunakan siswa dalam proses belajarmengajar itu sudah baik, tetapi sumber belajar siswa sangat terbatas mengenai pelajaran matematika karena hanya menggunakan buku paket saja, buku yang digunakan juga kurang bervariasi dan daya tariknya untuk menambah semangat belajar siswa. Maka dengan LKS yang dikembangkan akan menambahkan sumber belajar siswa dan lebih bervariasi sehingga dapat memotivasi siswa untuk belajar. Dalam kurikulum 2013 salah satu tugas guru adalah mengembangkan bahan ajar, yang salah satunya adalah mengembangkan LKS agar menjadi bahan ajar yang mampu menunjang dalam proses pembelajaran. Maka dari itu, perlu adanya pengembangan bahan ajar yang menghubungkan materi pembelajaran dengan permasalahan yang nyata agar mempermudah proses pembelajaran.

Berdasarkan permasalahan di atas, maka tujuan penelitian ini yaitu mengembangkan Lembar Kerja Siswa berbasis Pendekatan Saintifik pada materi Himpunan di Kelas VII SMP Xaverius Lubuklinggau.

\section{METODE}

Dalam penelitian ini digunakan metode Research and Development (R\&D). Menurut Sugiyono (2013) penelitian pengembangan (R\&D) Research-Based Development atau pengembangan berbasis penelitian yaitu metode penelitian yang digunakan untuk menghasilkan produk tertentu dan menguji keefektifan produk yang dibuat. Penelitian ini menghasilkan produk bahan ajar berupa Lembar Kerja Siswa berbasis Pendekatan Saintifik tentang materi himpunan. Adapun desain dan pengembangan LKS menggunakan model pengembangan ADDIE yang terdiri atas 5 tahapan yaitu: Analysis (analisis), Design (desain), dan Development (pengembangan), Implementation (implementasi), dan Evaluation (evaluasi).

\section{Tahap Analisis (Analysis)}

Pada tahap analisis ini terdiri dari analisis kebutuhan dan analisis kompetensi dan instruksional.

a) Analisis Kebutuhan

Tahap analisis kebutuhan berkaitan dengan kompetensi yang akan dipelajari peserta didik untuk meningkatkan hasil belajar.

b) Analisis Kompetensi dan Instruksional

Tahap analisis kompetensi dan instruksional, dilaksanakan analisis kompetensi yang dituntut kepada peserta didik, kompetensi apa saja yang harus dikuasai oleh peserta didik setelah menggunakan produk pengembangan, 
pertanyaan ini berkaitan dengan segala kemampuan belajar yang ingin dicapai oleh peserta didik setelah memanfaatkan produk pengembangan dalam pembelajaran, baik itu pengetahuan, sikap, maupun keterampilan.

\section{Tahap Desain (Design)}

Tahap desain merupakan tahap perancangan media, menentukan proses yang sistematik dimulai dari menetapkan tujuan pembelajaran, skenario pembelajaran, merancang perangkat pembelajaran, merancang materi pembelajaran dan alat evaluasi hasil belajar. Berikut merupakan tahap rancangan pembelajaran:

a) Penyusunan Rancangan LKS

1) Menyusun peta kebutuhan LKS

2) Menyusun kerangka LKS

3) Penyusunan sistematika LKS

4) Pengumpulan buku referensi

b) Membuat instrumen penelitian

Instrumen penelitian dengan memperhatikan aspek penilaian kevalidan LKS yaitu aspek komponen kelayakan isi, kelayakan penyajian, kelayakan bahasa. Pada kegiatan ini dilakukan dengan cara membuat instrumen penelitian yang meliputi penilaian oleh ahli bahasa, ahli materi, dan ahli media serta angket kepraktisan siswa.

\section{Tahap Pengembangan (Development)}

Pada tahap ini berisikan kegiatan realisasi rancangan produk. Dalam tahap desain, telah disusun kerangka konseptual pengembangan Lembar Kerja Siswa yang akan dilakukan pada para ahli dan kelompok kecil. Sebelum diujicoba, LKS terlebih dahulu divalidasi oleh para ahli yang meliputi ahli bahasa, ahli materi, dan ahli media. Setelah dilakukan validasi dari para ahli, langkah selanjutnya revisi hasil dari penilaian ketiga ahli tersebut. Lembar Kerja Siswa yang sudah divalidasi dan direvisi oleh para ahli selanjutnya diujicobakan kepada siswa.

Proses pengembangan ini terdiri beberapa tahapan yaitu sebagai berikut:

a. Pengembangan LKS

LKS yang akan dikembangkan berdasarkan spesifikasi sebagai berikut:

1) LKS berbentuk media cetak

2) Disusun dengan menggunakan pendekatan saintifik

3) Disusun dengan menggunakan bantuan microsoft word 2010

4) Disusun dengan memperhatikan komponen yang harus ada pada LKS

b. Validasi ahli

Bahan ajar LKS yang dihasilkan kemudian divalidasi oleh ahli bahasa, ahli materi, dan ahli media. Validasi dilakukan guna untuk mendapatkan penilaian dan masukan untuk melakukan pengembangan dan perbaikan LKS serta mengetahui kevalidan LKS yang akan diujicobakan.

c. Revisi produk

Bahan ajar yang telah divalidasi kemudian dianalisis dan direvisi sesuai dengan saran para ahli. Validasi dilakukan sampai mendapatkan hasil yang valid.

\section{Tahap Implementasi (Implementation)}

Setelah LKS dinyatakan valid oleh para ahli, LKS tersebut diujicobakan pada siswa kelas VII SMP Xaverius Lubuklinggau yang telah ditentukan sebagai tempat penelitian. Setelah LKS direvisi, maka LKS tersebut diujicobakan lagi pada subjek penelitian untuk menguji kualitas LKS pada materi himpunan. Tahap ini akan menghasilkan data berupa penilaian LKS. Data yang diperoleh dengan cara 
membagikan lembar evaluasi berupa angket kepraktisan siswa. Angket dibagikan setelah siswa melaksanakan pembelajaran dengan menggunakan LKS yang telah dikembangkan.

\section{Tahap Evaluasi (Evaluation)}

Tahap evaluasi dilakukan pada setiap tahap model pengembangan, hal ini bertujuan agar dalam setiap tahap yang dilalui memperoleh hasil yang maksimal. Tahap ini merupakan tahap penilaian kualitas terhadap kepraktisan LKS yang dikembangkan yang dilihat dari data hasil perhitungan angket kepraktisan siswa. Pada tahap ini juga dilakukan pengukuran terhadap kepraktisan LKS dengan Pendekatan Saintifik pada materi himpunan yang dikembangkan. Selain itu juga dilakukan revisi terhadap LKS sesuai dengan hasil evaluasi yang belum dapat dipenuhi oleh LKS.

\section{HASIL DAN PEMBAHASAN}

\section{Tahap Analisis (Analysis)}

Tahap analisis ini dilakukan untuk mengetahui kebutuhan yang diperlukan untuk menghasilkan LKS yang berkualitas. Tahap ini meliputi analisis kebutuhan, analisis kompetensi dan analisis instruksional siswa kelas VII. Hasil analisis pada tahap ini sebagai berikut.

a) Analisis Kebutuhan

Hasil dari analisis kebutuhan yang dilakukan pada tanggal 18 Januari 2019 menunjukkan bahwa guru tidak menggunakan LKS dalam proses pembelajaran dan hanya menggunakan buku paket dari Kemendikbud 2016. Berdasarkan hasil pengamatan, diketahui bahwa penggunaan LKS dalam proses pembelajaran matematika sangat mempengaruhi prestasi akademik siswa. Dalam kurikulum 2013 salah satu tugas guru adalah mengembangkan bahan ajar, yang salah satunya adalah mengembangkan LKS agar menjadi bahan ajar yang mampu menunjang proses pembelajaran.

Berdasarkan hasil observasi yang dilakukan pada tanggal 18 Januari 2019, guru SMP Xaverius Lubuklinggau menggunakan buku cetak sebagai bahan ajar dalam proses pembelajaran. Buku cetak tersebut memuat uraian materi, contoh soal, latihan soal. Penggunaan LKS dalam proses pembelajaran tidak ada, namun dalam LKS yang sudah ada, penggunaan LKS bukan bagian dari proses pembelajaran yang memberikan pengetahuan karena LKS yang digunakan tidak memuat peta konsep, hanya berisi ringkasan materi, latihan dan soal yang diberikan tidak berkaitan dengan masalah sehari-hari, dan tidak menyajikan kolom untuk siswa menyimpulkan pembelajaran. Sulit ditemui LKS yang memberikan tahapan-tahapan dalam menemukan penyelesaian dari masalah yang diberikan. Dari hasil wawancara yang dilakukan dengan guru matematika SMP Xaverius Lubuklinggau, peran LKS sangatlah penting dalam proses pembelajaran untuk melatih keterampilan siswa dalam melalui tahapantahapan yang diberikan untuk mempermudah siswa dalam menemukan penyelesaian dari soal yang diberikan.

Dari kondisi tersebut, maka dipandang perlu untuk mengembangkan LKS yang mampu membuat siswa lebih aktif dan mampu berkomunikasi dengan baik dalam proses pembelajaran, serta mampu melatih siswa untuk mandiri dan kreatif dalam menyelesaikan masalah. Salah satu bahan ajar yang sesuai dengan kebutuhan tersebut adalah LKS berbasis Pendekatan Saintifik. Karena 
pembelajaran dengan menggunakan LKS berbasis Pendekatan Saintifik membuat siswa mampu menyelesaikan masalah yang disajikan berdasarkan kehidupan sehari-hari.

b) Analisis Kompetensi dan Instruksional

Setelah dilakukan observasi diketahui bahwa SMP Xaverius Lubuklinggau menggunakan Kurikulum 2013 (K13). Kompetensi dasar yang berkaitan dengan materi Himpunan yang akan dikembangkan adalah menjelaskan pengertian himpunan, himpunan bagian, komplemen himpunan, operasi himpunan, dan menunjukkan contoh dan bukan contoh. Selain berkaitan dengan tuntutan dari kurikulum 2013 yang bertujuan untuk mendorong siswa agar lebih baik dalam melakukan observasi, bertanya dan mengkomunikasikan (mempresentasikan) yang mereka peroleh atau mereka ketahui setelah menerima materi pembelajaran diperlukan sebuah LKS berbasis saintifik yang dapat membantu proses pembelajaran, menyajikan permasalahan yang harus dipecahkan bersama sehingga terciptanya kegiatan pembelajaran yang mampu melatih kemampuan memecahkan masalah dan dapat meningkatkan kerjasama dan tanggung jawab siswa dalam menemukan konsep. Pendekatan Saintifik adalah metode pembelajaran yang mampu menghubungkan materi pembelajaran himpunan dengan permasalahan yang nyata sehingga dapat mempermudah proses pembelajaran dengan menghadirkan gambar dan bentuk visual secara kontekstual. Berdasarkan analisis tersebut, LKS dengan Pendekatan Saintifik dapat diterapkan untuk siswa SMP kelas VII.

\section{Tahap Desain (Design)}

Hasil dari tahap analisis dijadikan sebagai dasar dalam membuat desain LKS. Adapun yang harus dilakukan dalam tahap desain yaitu penyusunan rancangan LKS dan membuat instrumen penelitian. Berikut merupakan proses yang dilakukan pada tahap desain.

a) Penyusunan Rancangan LKS

1) Menyusun peta kebutuhan LKS

Penyusunan peta kebutuhan LKS akan lebih mudah jika telah melakukan analisis kurikulum. Hasil dari penyusunan peta kebutuhan LKS memberikan keterangan tentang banyaknya LKS yang harus dibuat. Peta kebutuhan LKS disajikan untuk merancang Lembar Kerja Siswa yang akan dibuat.

2) Menyusun kerangka LKS

LKS yang dikembangkan dalam penelitian ini terdiri dari tiga bagian, yaitu bagian awal, bagian isi dan bagian akhir. Bagian awal terdiri dari halaman sampul depan, halaman identitas LKS, kata pengantar, peta konsep, dan daftar isi. Pada bagian isi terdapat seluruh kegiatan yang dilakukan siswa untuk mendapatkan pengetahuan sesuai dengan KD 3.4 dan 4.4 tentang menjelaskan pengertian himpunan, himpunan bagian, komplemen himpunan, operasi himpunan, dan menunjukkan contoh dan bukan contoh.

3) Penyusunan sistematika LKS

Sistematika penyajian materi dalam LKS ini adalah menyajikan kompetensi dasar dan indikator pencapaian penggunaan LKS, terdapat 5 langkah dalam setiap indikatornya, langkah pertama menjelaskan tujuan pembelajaran, langkah kedua menanya masalah-masalah yang berkaitan dengan 
kehidupan sehari-hari, kemudian disediakan kolom-kolom untuk menyelesaikan masalah yang disajikan. Langkah ketiga menyajikan latihan soal kemudian siswa mencoba untuk menjawabnya, langkah keempat menyajikan kolom untuk menalar latihan soal yang diberikan, dan langkah kelima terdiri dari simpulan yang berisi ringkasan dari keempat langkah sebelumnya.

4) Pengumpulan buku referensi

b) Membuat Instrumen Penelitian

Instrumen yang dibuat dalam penelitian ini terdiri dari dua macam, yaitu instrumen penilaian kevalidan LKS berupa angket ahli dan penilaian kepraktisan berupa angket kepraktisan siswa. Penilaian kevalidan berupa angket ahli terdiri atas penilaian tiga ahli yaitu ahli bahasa, ahli materi, dan ahli media. Berikut penjelasan dari instrumen kevalidan dan kepraktisan LKS.

1) Instrumen Penilaian Kevalidan LKS

Pembuatan instrumen penilaian kevalidan LKS mengacu pada kriteria LKS yang baik menurut Badan Standar Nasional Pendidikan (BSNP). Instrumen ini terdiri dari 3 jenis, yaitu instrumen penilaian LKS oleh ahli bahasa, instrumen penilaian LKS oleh ahli materi, dan instrumen penilaian LKS oleh ahli media. Ketiga instrumen tersebut berupa angket dengan skala Likert terdiri dari pernyataan dengan 4 alternatif jawaban, yaitu 1, 2, 3, dan 4 yang masing-masing menunjukkan penilaian sangat tidak setuju, tidak setuju, setuju, dan sangat setuju. Instrumen tersebut digunakan untuk menilai kualitas LKS yang dikembangkan berdasarkan komponen kelayakan bahasa, kelayakan isi, kelayakan penyajian, aspek penilaian Pendekatan Saintifik, kelayakan kegrafikan.

2) Instrumen penilaian kepraktisan LKS

Pembuatan instrumen penilaian kepraktisan LKS berdasarkan aspek kemudahan dan kemanfaatan. Instrumen penilaian kepraktisan LKS ini berupa angket kepraktisan siswa. Angket kepraktisan siswa terhadap kepraktisan LKS yang dikembangkan ini disusun dengan skala Likert dengan empat alternatif penilaian, yaitu sangat tidak setuju, tidak setuju, setuju, dan sangat setuju yang dikonversikan ke dalam skor 1, 2, 3 dan 4 secara berurutan. Angket kepraktisan siswa terdiri dari 20 pernyataan yang mengacu pada 4 komponen dasar dalam instrumen penilaian kevalidan LKS yaitu komponen isi, bahasa, penyajian, dan kegrafikan.

\section{Tahap Pengembangan (Development)}

Tahap ini terdiri dari pengembangan LKS, validasi dan revisi LKS. Tahap pengembangan bertujuan untuk menghasilkan LKS dengan Pendekatan Saintifik yang sudah divalidasi dan direvisi berdasarkan masukan para ahli dan hasil ujicoba kepada siswa.

a) Validasi LKS

Draf LKS yang dihasilkan selanjutnya divalidasi oleh tiga dosen ahli dari STKIP PGRI Lubuklinggau (ahli bahasa, ahli materi, dan ahli media). Validasi yaitu penilaian LKS pada setiap aspek yang ditanyakan pada lembar penilaian dilihat dari komponen kelayakan isi, kelayakan penyajian, aspek penilaian Pendekatan Saintifik, kelayakan bahasa, dan kelayakan kegrafikan. Selain itu, dalam validasi ini validator memberi komentar dan saran untuk perbaikan 
LKS. Selanjutnya hasil penilaian dan saran digunakan untuk merevisi LKS.

b) Penilaian Ketiga Ahli

Berdasarkan keseluruhan penilaian kevalidan LKS dari tiga orang ahli yaitu ahli bahasa, ahli materi, dan ahli media terhadap LKS dengan Pendekatan Saintifik yang sudah diuraikan di atas menunjukkan bahwa LKS yang dikembangkan dikategorikan valid dengan skor rata-rata keseluruhan sebesar 3,15. Rekapitulasi hasil keseluruhan penilaian kevalidan dari tiga ahli dapat dilihat pada tabel 1.

Tabel 1. Rekapitulasi penilaian ahli

\begin{tabular}{cccccc}
\hline No & Validator & $\begin{array}{c}\text { Jumlah butir } \\
\text { pernyataan }\end{array}$ & $\begin{array}{c}\text { Skor yang } \\
\text { diperoleh }\end{array}$ & $\begin{array}{c}\text { Skor rata- } \\
\text { rata ahli }\end{array}$ & Kategori \\
\hline 1 & Ahli bahasa & 14 & 43 & 3,07 & Valid \\
2 & Ahli materi & 22 & 73 & 3,32 & Sangat valid \\
3 & Ahli media & 26 & 79 & 3,04 & Valid \\
\hline & Total & 62 & 195 & 3,15 & Valid \\
\hline
\end{tabular}

Sehingga seluruh komponen termasuk dalam kategori valid dengan skor rata- rata keseluruhan sebesar 3,15 dengan skor maksimal 4,00.

c) Ujicoba Kelompok Kecil

Pelaksanaan ujicoba kelompok kecil dilaksanakan pada hari Senin tanggal 9 September 2019 yang terdiri dari 6 siswa diambil secara heterogen, yang memiliki tingkat kemampuan rendah, sedang dan tinggi. Berdasarkan hasil perhitungan angket ujicoba kelompok kecil, diperoleh 6 siswa yang menunjukkan respon positif terhadap LKS berbasis Pendekatan Saintifik dengan memperoleh skor rata-rata sebesar 3,49. Hasil dari penilaian angket ujicoba kelompok kecil dikategorikan Sangat Praktis dan menunjukkan tidak perlu adanya revisi terhadap LKS yang dikembangkan. Dengan demikian, LKS yang dikembangkan dapat digunakan pada tahap ujicoba kelompok besar.

\section{Tahap Implementasi (Implementation)}

Setelah LKS dinyatakan valid dan sangat praktis oleh para ahli dan pada ujicoba kelompok kecil, LKS tersebut diujicobakan kembali pada kelas VII.C SMP Xaverius Lubuklinggau yang berjumlah 32 siswa. Ujicoba kelompok besar dilakukan pada hari Rabu tanggal 11 September 2019. Ujicoba LKS siswa dilakukan pada siswa kelas VII.C SMP Xaverius Lubuklinggau yang berjumlah 32 siswa. Selama proses pembelajaran, siswa dibimbing dengan panduan LKS dan RPP yang telah disiapkan. Berdasarkan hasil perhitungan angket ujicoba kelompok besar diperoleh skor rata-rata sebesar 3,43. Dengan demikian hasil perhitungan angket kepraktisan siswa terhadap LKS yang dikembangkan dikategorikan Sangat Praktis.

\section{Tahap Evaluasi (Evaluation)}

Pada tahap evaluasi, data dari analisis angket kepraktisan siswa kemudian dianalisis. Analisis angket kepraktisan siswa bertujuan untuk mengetahui respon kepraktisan siswa terhadap LKS yang dikembangkan dan untuk mengetahui kepraktisan LKS yang dikembangkan. Masukan dan revisi dalam setiap tahapan pengembangan dilakukan untuk menghasilkan media pembelajaran LKS yang layak digunakan untuk siswa dalam pembelajaran. Hasil cuplikan media pembelajaran LKS yang dikembangkan dapat dilihat pada gambar di bawah ini: 


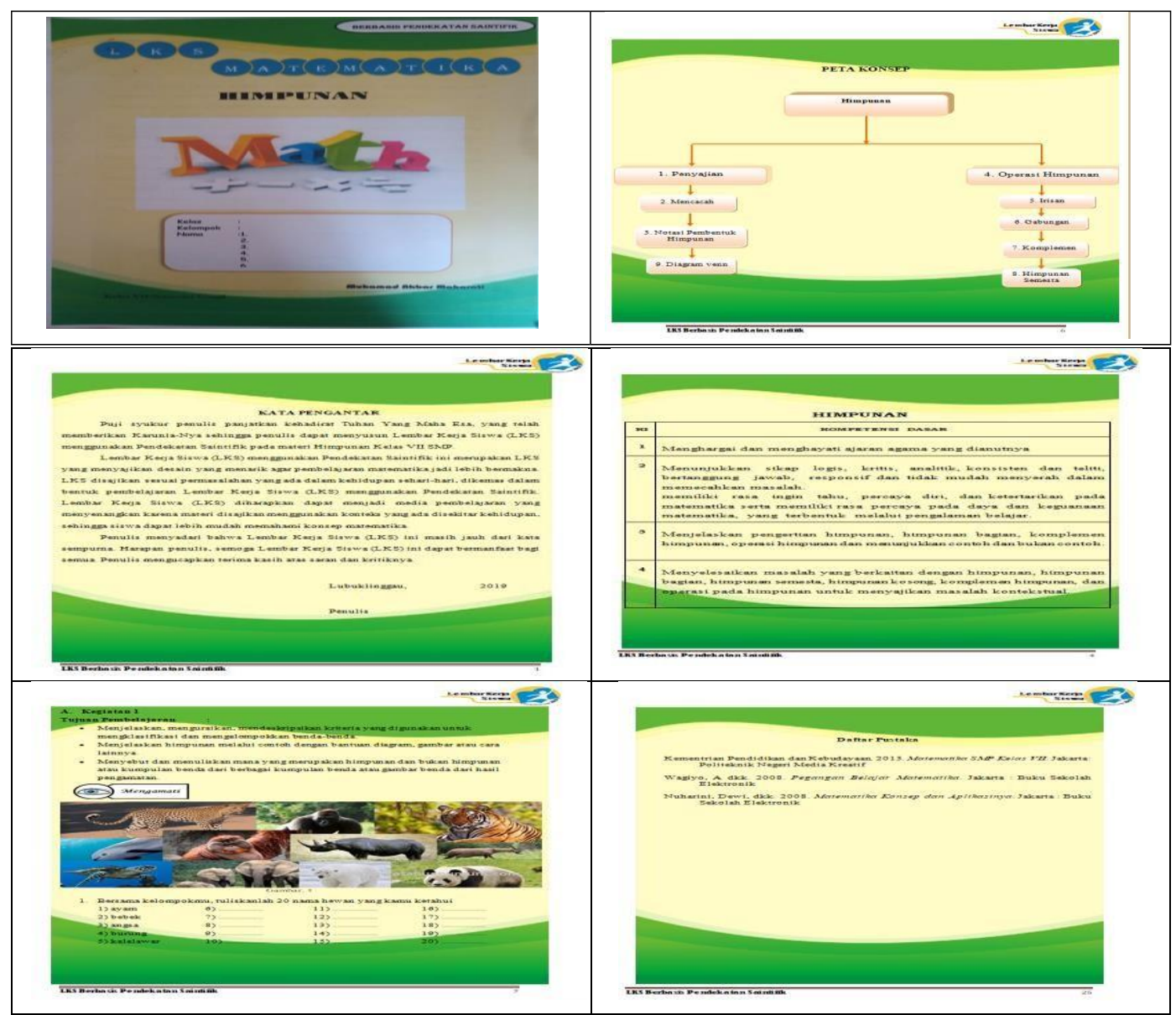

Gambar 1. Hasil dan cuplikan media pembelajaran LKS yang dikembangkan

Beberapa peneliti lain juga telah mengembangkan LKS berbasis pendekatan saintifik, seperti: (1) Fitriana, Yusuf, dan Susanti (2016) mengembangkan LKS siswa menggunakan pendekatan saintifik untuk melihat berpikir kritis siswa pada materi perbandingan, LKS yang dikembangkan dinyatakan valid, praktis, dan memilik efek potensial; (2) Romiati dan Theis (2017) mengembangkan LKS berbasis pendekatan saintifik dan strategi pembelajaran PQ4R pada materi himpunan, LKS yang dikembangkan dinyatakan valid, praktis, dan efektif; (3) Hidayah (2019) mengembangkan LKPD dengan menggunakan pendekatan saintifik pada materi Operasi Hitung Aljabar berdasarkan kesulitan belajar siswa kelas VIII SMP, LKS yang dikembangkan dinyatakan valid, efektif, dan layak dan sangat menarik untuk digunakan peserta didik dalam pembelajaran matematika khususnya materi operasi hitung aljabar. Dengan demikian, pengembangan LKS ini telah menambah khazanah bahan ajar bagi siswa agar lebih mudah memperoleh bahan ajar khususnya bahan ajar berbasis pendekatan saintifik pada materi himpunan untuk menunjang proses pembelajarannya.

\section{SIMPULAN DAN SARAN}

LKS yang dikembangkan dikategorikan "Valid" dengan skor rata-rata 3,15 
ditentukan berdasarkan penilaian LKS oleh 3 dosen ahli dengan skor maksimal 4,00. LKS ini juga menunjukkan kriteria "Sangat Praktis" dengan rata-rata skor sebesar 3,43 ditentukan berdasarkan hasil respon siswa terhadap LKS.

LKS yang dikembangkan dalam penelitian ini dikategorikan Valid dan Sangat Praktis sehingga dapat dijadikan salah satu alternatif media pembelajaran oleh siswa dan guru sebagai penunjang kegiatan pembelajaran matematika berbasis Pendekatan Saintifik pada materi Himpunan. Pengembangan LKS berbasis Pendekatan Saintifik pada materi Himpunan dapat dijadikan penelitian lanjutan sampai ke tahap efektifitas.

\section{DAFTAR PUSTAKA}

Anwar, R. 2014. Hal-hal yang Mendasari Penerapan Kurikulum 2013. HUMANIORA, Vol. 5(1) : 97-106.

Daryanto. 2014. Pendekatan Pembelajaran Saintifik Kurikulum 2013. Yogyakarta: Gava Media.

Fitriana, D., Yusuf, M., dan Susanti, E. 2016. Pengembangan Lembar Kerja Siswa Menggunakan Pendekatan Saintifik Untuk Melihat Berpikir Kritis Siswa Materi Perbandingan. Jurnal Pendidikan Matematika, Vol. 10(2) : 23-38.

Hidayah, F. 2019. Pengembangan Lembar Kerja Peserta Didik (LKPD) dengan Menggunakan Pendekatan Saintifik Pada Materi Operasi Hitung Aljabar Berdasarkan Kesulitan Belajar Kelas VIII SMP. Skripsi tidak diterbitkan. Lampung: UIN Raden Intan Lampung. [Online].

Tersedia: http://repository.radenintan.ac.id/6896/1/SKRIPSI.pdf.

Jayanti, M. dan Wiratomo, Y. 2017. Perancangan Media Siap UN Matematika SMP Berbasis Android. Jurnal SAP (Susunan Artikel Pendidikan), Vol. 2(1) : 22-32.

Nasution, A. 2016. Pengembangan Modul Matematika Berbasis Masalah Untuk Meningkatkan Kemampuan Pemecahan Masalah Matematika Siswa. Rekognisi: Jurnal Pendidikan dan Kependidikan, Vol. 1(1) : 47-63.

Pebianto, A., Gunawan, G., Yohana, R., dan Nurjaman, A. 2019. Analisis Kemampuan Berpikir Kritis Siswa MTsN Kota Cimahi Pada Materi Persamaan Linear Dua Variabel Ditinjau dari Kepercayaan Diri. Journal on Education, Vol. 1(3) : 9-20.

Romiati, E. dan Theis, R. 2017. Pengembangan LKS Berbasis Pendekatan Saintifik dan Strategi Pembelajaran PQ4R Pada Materi Himpunan Kelas VII SMPN 11 Kota Jambi. Edumatica, Vol. 7(1) : 37-43.

Sufairoh. 2016. Pendekatan Saintifik \& Model Pembelajaran K-13. Jurnal Pendidikan Profesional, Vol. 5(3) : 116-125.

Sugiyono. 2013. Metode Penelitian Kuantitatif, Kualitatif dan R\&D. Bandung: Alfabeta.

Wijaya, A., Dewi, E.R.S., dan Purnamasari, V. 2018. Pembelajaran Model Team Assisted Individualization Terhadap Kemampuan Berpikir Kritis dan Hasil Belajar Siswa Sekolah Dasar. Elementary School, Vol. 5(1) : 31-37.

Zulfah. 2017. Tahap Preliminary Research Pengembangan LKPD Berbasis PBL Untuk Materi Matematika Semester 1 Kelas VIII SMP. Jurnal Cendekia: Jurnal Pendidikan Matematika, Vol. 1(2) : 1-12. 